\title{
Forecast, observation and modelling of a deep stratospheric intrusion event over Europe
}

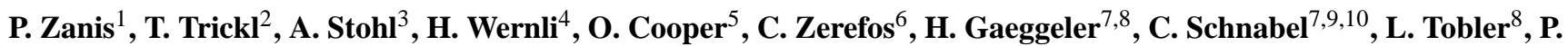 \\ W. Kubik ${ }^{11}$, A. Priller ${ }^{12}$, H. E. Scheel ${ }^{2}$, H. J. Kanter ${ }^{2}$, P. Cristofanelli ${ }^{13}$, C. Forster ${ }^{3}$, P. James ${ }^{3}$, E. Gerasopoulos ${ }^{14}$, A. \\ Delcloo $^{15}$, A. Papayannis ${ }^{16}$, and H. Claude ${ }^{17}$ \\ ${ }^{1}$ Research Center for Atmospheric Physics and Climatology, Academy of Athens, Athens, Greece \\ ${ }^{2}$ Forschungszentrum Karlsruhe, IMK-IFU, Garmisch-Partenkirchen, Germany \\ ${ }^{3}$ Lehrstuhl für Bioklimatologie und Immissionsforschung Technische Universität München, Freising, Germany \\ ${ }^{4}$ Atmospheric Physics, ETHZ, Zurich, Switzerland \\ ${ }^{5}$ Cooperative Institute for Research in Environmental Sciences, University of Colorado, Boulder/NOAA Aeronomy \\ Laboratory, Boulder, USA \\ ${ }^{6}$ Laboratory of Climatology and Atmospheric Environment, National and Kapodistrian University of Athens, Greece \\ ${ }^{7}$ Departement für Chemie und Biochemie, Universität Bern, Switzerland \\ ${ }^{8}$ Paul Scherrer Institute, Villigen PSI, Switzerland \\ ${ }^{9}$ Inst. Particle Physics, ETH Hoenggerberg, Switzerland \\ ${ }^{10}$ Scottish Universities Environmental Research Centre, East Kilbride, U.K. \\ ${ }^{11}$ Paul Scherrer Institute, c/o ETH Hoenggerberg, Switzerland \\ ${ }^{12}$ Institut fr Isotopenforschung und Kernphysik, Universität Wien, Austria \\ ${ }^{13}$ Institute of Atmospheric Sciences and Climate, Bologna, Italy \\ ${ }^{14}$ Nuclear Physics Department, Aristotle Univ. of Thessaloniki, Greece \\ ${ }^{15}$ Royal Meteorological Institute KMI, Uccle, Belgium \\ ${ }^{16}$ Department of Physics, National Technical University of Athens, Greece \\ ${ }^{17}$ Deutscher Wetterdienst, Meteorologisches Observatorium Hohenpeißenberg, Germany
}

Received: 23 December 2002 - Published in Atmos. Chem. Phys. Discuss.: 27 February 2003

Revised: 26 May 2003 - Accepted: 4 June 2003 - Published: 18 June 2003

\begin{abstract}
A wide range of measurements was carried out in central and southeastern Europe within the framework of the EU project STACCATO (Influence of StratosphereTroposphere Exchange in a Changing Climate on Atmospheric Transport and Oxidation Capacity) with the principle goal to create a comprehensive data set on stratospheric air intrusions into the troposphere along a rather frequently observed pathway over central Europe from the North Sea to the Mediterranean Sea. The measurements were based on predictions by suitable quasi-operational trajectory calculations using ECMWF forecast data. A predicted deep Stratosphere to Troposphere Transport (STT) event, encountered during the STACCATO period on 20-21 June 2001, was followed by the measurements network almost from its inception. Observations provide evidence that the intrusion affected large parts of central and southeastern Europe. Especially, the ozone lidar observations on 20-21 June 2001
\end{abstract}

Correspondence to: P. Zanis (pzanis@geol.uoa.gr) at Garmisch-Partenkirchen, Germany captured the evolution of two marked tongues of high ozone with the first one descending to nearly $2 \mathrm{~km}$, thus providing an excellent data set for model intercomparisons and validation. In addition, for the first time to our knowledge concurrent surface measurements of the cosmogenic radionuclides ${ }^{10} \mathrm{Be}$ and ${ }^{7} \mathrm{Be}$ and their ratio ${ }^{10} \mathrm{Be} /{ }^{7} \mathrm{Be}$ are presented together as stratospheric tracers in a case study of a stratospheric intrusion. The ozone tracer columns calculated with the FLEXPART model were found to be in good agreement with water vapour satellite images, capturing the evolution of the observed dry streamers of stratospheric origin. Furthermore, the time-height cross section of ozone tracer simulated with FLEXPART over Garmisch-Partenkirchen captures many details of the evolution of the two observed high-ozone filaments measured with the IFU lidar, thus demonstrating the considerable progress in model simulations. Finally, the modelled ozone (operationally available since October 1999) from the ECMWF (European Centre for Medium-Range Weather Forecasts)

(C) European Geosciences Union 2003 
atmospheric model is shown to be in very good agreement with the observations during this case study, which provides the first successful validation of a chemical tracer that is derived operationally from a weather forecast model. This suggests that coupling chemistry and weather forecast models may significantly improve both weather and chemical forecasts in the future.

\section{Introduction}

Stratosphere-Troposphere Exchange (STE), understood as the flux of air or trace constituents across the tropopause, is one of the key factors controlling the budgets of ozone, water vapour and other substances in both the troposphere and the lower stratosphere. The term STE includes both directions; the Stratosphere to Troposphere Transport (STT) and Troposphere to Stratosphere Transport (TST). Although there is a long scientific debate in the literature over the last four decades on the relative contribution from photochemistry and STT on the origin of background tropospheric ozone (Junge, 1962; Crutzen, 1973; Chameides and Walker, 1973; Fabian and Pruchniewicz, 1977; Singh et al., 1978; Logan, 1985; Penkett and Brice, 1986; Austin and Follows, 1991; Follows and Austin, 1992; Davies and Schuepbach, 1994; Holton et al., 1995; Appenzeller et al., 1996a; Roelofs and Lelieveld, 1997; Harris et al., 1998; Lelieveld and Dentener, 2000; Monks, 2000; Stohl et al., 2000) the cross-tropopause flux estimation is still a topic of great scientific interest.

In principle, the most common occurrences of STT in the extratropics are associated with tropopause folds, which are characterized by tongues of anomalously high potential vorticity (PV) extending equatorward and formed through the isentropic transport within large-scale cyclonic and anticyclonic disturbances. However, still missing is a single comprehensive and quantitative picture of extratropical STE which would unify the mesoscale approach, which considers the tropopause folds, and the so-called "downward control principle", which is viewed from the global perspective (Holton et al., 1995; Stohl et al., 2003). Under certain circumstances, some parts of these tongues may be stretched out into elongated filaments, and under others may roll up to form isolated coherent structures containing high PV air (cutoff lows) (Holton et al., 1995). Deep and intense intrusions of stratospheric air penetrating down to lower tropospheric levels or even to the surface are more relevant than the shallow ones for atmospheric chemistry as they clearly lead to irreversible mixing of stratospheric with tropospheric air and hence to tropospheric composition changes.

Although STT processes associated with mid-latitude tropopause folds have been widely studied over the last four decades using both observational case studies and numerical models, as reviewed by WMO (1986), Davies and Schuepbach (1994), Holton et al. (1995), and Stohl et al. (2003), there is just a limited number of case studies characterising a deep intrusion event on its way down to the lower troposphere, based on both measurements and modelling. Lidar sounding has a great potential for such investigations (Ancellet et al., 1991; Langford et al., 1996; Browell et al., 1998; Stohl and Trickl, 1999). Eisele et al. (1999), using lidar sounding data during a large number of STT events, found that only a few deep intrusions reach a level of $3000 \mathrm{~m}$. Only the most vigorous events can produce low altitude spikes in measured stratospheric tracer concentrations such as $\mathrm{O}_{3}$, $\mathrm{H}_{2} \mathrm{O}, \mathrm{PV},{ }^{7} \mathrm{Be}$, and ${ }^{10} \mathrm{Be}$ that are distinct enough to draw the attention of the analyst to a possible stratospheric influence. At least at high mountain peaks there is a higher possibility of an observable stratospheric influence (Zanis et al., 1999; Stohl et al., 2000). Elbern et al. (1997) performed a statistical assessment of deep intrusions based on ten years records of ${ }^{7} \mathrm{Be}$, ozone, and relative humidity at two Alpine stations, Zugspitze and Wank, in Germany and found that direct deep stratospheric intrusions affect Zugspitze (2962 m asl) during $5 \%$ of the time while they affect Wank $(1776 \mathrm{~m}$ asl $)$ less than $2.5 \%$. A more recent analysis by James et al. (2002) based on a different data filtering approach yielded an average annual stratospheric ozone fraction of $8.8 \%$ for pronounced intrusions at the Zugsitze summit. A similar statistical assessment carried out for three years at Jungfraujoch ( $3580 \mathrm{~m}$ asl), Switzerland, Sonnblick (3106 m asl), Austria and Zugspitze by Stohl et al. (2000), showed that the average observed intrusion frequencies are 17\%, 10\%, and 7\%, respectively. However, in all these studies the absolute frequency of deep stratospheric intrusions depends critically on the specification of threshold values for ${ }^{7} \mathrm{Be}$, ozone, and relative humidity.

Although the stratospheric tracers $\mathrm{O}_{3}, \mathrm{H}_{2} \mathrm{O}, \mathrm{PV}$ and ${ }^{7} \mathrm{Be}$ have been widely used so far for both climatological and case studies of STT, there are only very few studies, which are mainly climatological, making use of measurements of the cosmogenic radionuclide ${ }^{10} \mathrm{Be}$ and the ratio ${ }^{10} \mathrm{Be} /{ }^{7} \mathrm{Be}$ (Dibb et al., 1994; Jordan et al., 2003). The cosmogenic radionuclides ${ }^{7} \mathrm{Be}$ and ${ }^{10} \mathrm{Be}$ are produced through spallation reactions mainly in the stratosphere but they cannot be considered as ideal stratospheric tracers because they attach to aerosols and hence their tropospheric lifetime is significantly controlled by wet scavenging processes. A way around the difficulties with wet deposition is to use the concentration ratio of the two radionuclides because both species are washed out in the same way (Raisbeck et al., 1981). In addition, the ratio of ${ }^{10} \mathrm{Be} /{ }^{7} \mathrm{Be}$ can also be used to trace stratospheric air, like ${ }^{10} \mathrm{Be}$ and ${ }^{7} \mathrm{Be}$ independently because the ratio values in the stratosphere (especially in the lower stratosphere) are much higher than in the troposphere due to the much longer half-life of ${ }^{10} \mathrm{Be}\left(1.5110^{6} \mathrm{yr}\right)$ compared to ${ }^{7} \mathrm{Be}(53.12 \mathrm{~d})$ and the relatively long residence time of stratospheric air masses ranging from months to years (Raisbeck et al., 1981). Recently, three case studies based on aircraft samples showed that ${ }^{10} \mathrm{Be} /{ }^{7} \mathrm{Be}$ ratios, when determined in the context of other chemical 
constituents, can provide insight into the various mechanisms of STT (Jordan et al., 2003). However, in contrast to ${ }^{7} \mathrm{Be}$, which is measured regularly with high-resolution gamma-ray spectrometry at Alpine peak stations, regular ${ }^{10} \mathrm{Be}$ measurements are scarce, especially in Europe, because its detection requires accelerator mass spectrometry, which is an expensive method for continuous monitoring. In the framework of STACCATO, combined measurements of ${ }^{10} \mathrm{Be}$ and ${ }^{7} \mathrm{Be}$ were carried out regularly throughout the course of a full year at Jungfraujoch and Zugspitze. A climatological study of these ${ }^{7} \mathrm{Be}$ and ${ }^{10} \mathrm{Be}$ measurements and their ratio was presented by Zanis et al. (2003) and it was reported that for the majority of the cases within the upper $10 \%$ quantile of ${ }^{10} \mathrm{Be} /{ }^{7} \mathrm{Be}$ ratios measured at Zugspitze during 2000, the 10-day back trajectories indicated a direct stratospheric source.

A few of the direct deep stratospheric intrusions have been modelled adequately with numerical simulations. Schuepbach et al. (1999a; 1999b) simulated two episodes at Jungfraujoch with doubly nested mesoscale (14 km horizontal resolution) versions of the "Europa Model" (EM) and "High Resolution Model" (HM) operated by the German and Swiss Weather Services, while Stohl et al. (2000) investigated two episodes over the Alps using a special version of the stochastic Langrangian model FLEXPART based on ECMWF data from the lowest 29 model levels with a horizontal resolution of $1^{\circ}$ and time resolution of $3 \mathrm{~h}$. The origin of relatively high surface ozone concentrations measured at Izana Observatory (Canary Islands) were also studied successfully using a coupled chemistry - GCM (ECHAM-4) at T63 resolution $\left(1.875^{\circ} \times 1.875^{\circ}\right)($ Kentarchos et al., 2000).

In the present study we provide observational evidence of a successfully forecast deep stratospheric intrusion event during 20-21 June 2001, based on a measurements network extending from central to southeastern Europe operated within the framework of the EU project STACCATO. Concurrent surface measurements of the cosmogenic radionuclides ${ }^{10} \mathrm{Be}$ and ${ }^{7} \mathrm{Be}$ and their ratio ${ }^{10} \mathrm{Be} /{ }^{7} \mathrm{Be}$ are used for the first time to our knowledge to investigate a stratospheric intrusion event. The observational evidence of this deep stratospheric intrusion event is further investigated and supported by model calculations with the Lagrangian particle model FLEXPART as well as with the ECMWF global analysis data of potential vorticity, relative humidity and ozone, water vapour (WV) satellite images and 3-D back trajectory analysis. It should be noted that a newly available product from ECMWF is the ozone field, which is analysed and forecast operationally along with the meteorological parameters at ECMWF since October 1999 and hence this study provides a first validation of this product.

\section{Data and methods}

\subsection{Description of forecast trajectories and measurements}

A wide range of measurements were carried out in central and southeastern Europe within the framework of the EUproject STACCATO with the principle goal to collect a comprehensive dataset on stratospheric air intrusions into the troposphere along a rather frequently observed pathway (Wernli and Bourqui, 2002; Sprenger and Wernli, 2003) over central Europe from the North Sea to the Mediterranean Sea. In order to cover a substantial amount of STE cases, coordinated measurements during short campaigns were carried out based on trajectory forecasts provided daily by ETH Zrich since November 2000. In a similar approach, Cooper et al. (1998) utilized forecasting techniques in order to time the launching of ozonesondes so that they intercepted tropopause folds. A warning call was issued whenever it was expected that a significant number of partner stations would be affected by an intrusion. These stratospheric intrusion forecasts, based on ECMWF forecasts, aided the measurement groups with the set-up and planning of the observations. Every twelve hours four-day forward trajectories were started from the entire region covering the Atlantic Ocean and western Europe between 250 and $600 \mathrm{hPa}$. From this large set of trajectories those that initially resided in the stratosphere (PV larger than $2 \mathrm{pvu}$ ) and descended during the following four days by more than $300 \mathrm{hPa}$ into the troposphere were selected as "stratospheric intrusion trajectories". The same selection criterion was used in a previous case study (Wernli, 1997) to study an intrusion associated with a major Atlantic cyclone.

Intense vertical ozone profile measurements by lidar and occasional ascents of balloon-borne ozonesondes were performed after a warning call was issued. ECC ozonesonde ascents took place occasionally at Thessaloniki, Greece (40.52 N, 22.97 E) and at San Pietro Capofiume, Italy (44.65 N, $11.62 \mathrm{E})$ while radiosonde measurements at both stations were also available for all warning calls. In the present study additional ozonesonde data from Hohenpeienberg, Germany, Uccle, Belgium, and Payerne, Switzerland, were provided by the respective sounding groups. Ozone-lidar measurements were carried out at Garmisch-Partenkirchen, Germany (47.5 $\mathrm{N}, 11.06 \mathrm{E}$ ), with the IFU lidar, and at Thessaloniki, Greece $(40.52 \mathrm{~N}, 22.97 \mathrm{E})$, with the AUTH-NTUA lidar.

The IFU ozone lidar (differential-absorption lidar, DIAL) is a three-wavelength lidar operated at $277 \mathrm{~nm}, 292 \mathrm{~nm}$ and $313 \mathrm{~nm}$. Separate receivers (equipped with $1.1-\mathrm{m}$ grating spectrographs each) are used for near-field and far-field detection. The operating range is 0.2 to $18 \mathrm{~km}$ under optimum conditions. A total of eight analogue and photon counting channels makes possible the retrieval and intercomparison of different overlapping ozone profiles. In this way, the technical performance of the system can be controlled. The accuracy of the system is approximately $3 \mathrm{ppb}$ up to $6 \mathrm{~km}$ and 


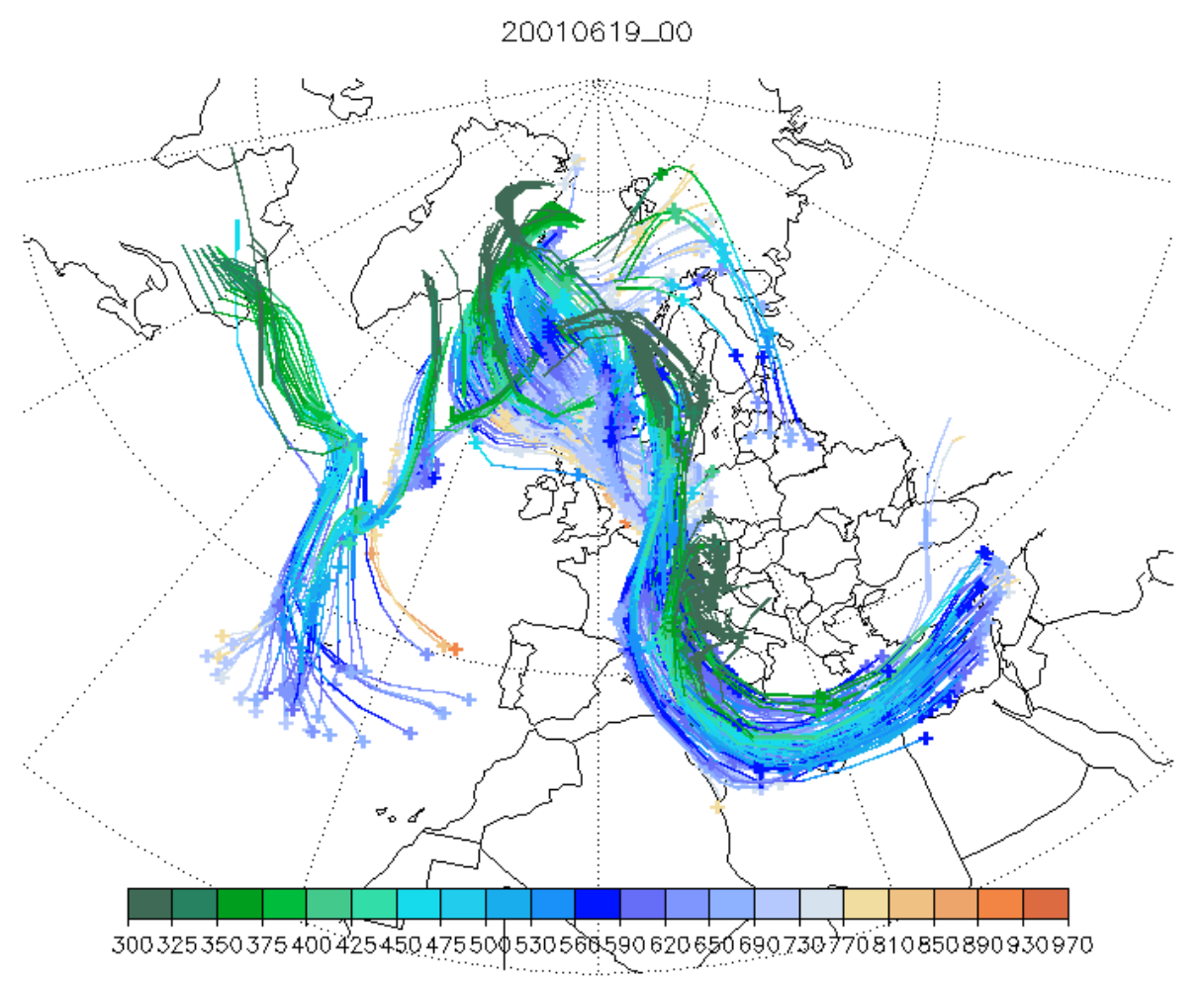

Fig. 1. Example of an operational STE forecast based upon ECMWF forecast data for the time period 19-23 June 2001 for stratospheric tracer released on 19 June, 00:00 UTC. The colour indicates the pressure value of the trajectories (in $\mathrm{hPa}$ ).

about $5 \mathrm{ppb}$ up to the tropopause, as verified by comparisons with measurements from the local summit stations and the Hohenpeienberg ozonesondes. A single measurement is completed within $45 \mathrm{~s}$ due to a $100 \mathrm{~Hz}$ repetition rate of the $\mathrm{KrF}$ pump laser. The IFU lidar was typically operated at intervals of $1 \mathrm{~h}$ in the absence of clouds.

Continuous measurements of ozone, ${ }^{7} \mathrm{Be}$ and meteorological data (relative humidity, temperature, pressure, wind speed and direction) have been carried out regularly at the highaltitude stations Jungfraujoch, Switzerland (46.53 N, 7.98 E, $3580 \mathrm{~m}$ asl), Zugspitze, Germany (47.4 N, 11.0 E, $2962 \mathrm{~m}$ asl), Sonnblick, Austria (47.05 N, $12.95 \mathrm{E}, 3106 \mathrm{~m}$ asl) and Mt. Cimone, Italy (44.12 N, $10.42 \mathrm{E}, 2165 \mathrm{~m}$ asl). In addition to the daily measurements of ${ }^{7} \mathrm{Be}$ (bi-daily for Jungfraujoch), bi-daily measurements of ${ }^{210} \mathrm{~Pb}$ were carried out at Jungfraujoch while regular measurements of ${ }^{10} \mathrm{Be}$ were performed at Jungfraujoch (bi-daily) and Zugspitze (daily) with accelerator mass spectrometry (AMS). Information on the ${ }^{7} \mathrm{Be}$ measurements at all stations can be found in Gerasopoulos et al. (2001) and on ${ }^{10} \mathrm{Be}$ in Zanis et al. (2003).

The stratospheric intrusion event presented here influenced a large part of Europe. Figure 1 shows the 4-day forecast trajectories for the time period 19-23 June 2001, where stratospheric air from the Polar region descended deeply towards central Europe and in parts towards Greece. In order to facilitate the interpretation of the trajectory plot (e.g. when exactly and at what altitude a stratospheric intrusion can be expected at a specific measurements site) "intrusion hit tables" for the sites Thessaloniki, Jungfraujoch, Garmisch, and Mt. Cimone were also issued daily. These are matrices of time (time step of 3 hours) versus altitude and contain a marker that indicates whether according to forecast trajectories the air at the respective altitude and time pertains to a deep stratospheric intrusion. For the case study presented here, the hit tables issued on 19 June 2001 at 00:00 UTC indicated that a stratospheric intrusion was expected to affect Jungfraujoch (625-675 hPa) from 03:00 to 18:00 UTC on 20 June 2001 (see Table 1) and Garmisch and Mt. Cimone down to $575 \mathrm{hPa}$ (not shown).

\subsection{Model description}

Model calculations of the transport of stratospheric air into the troposphere were performed with a special version of the Lagrangian particle dispersion model FLEXPART 4.0 (Stohl et al., 1998). FLEXPART was validated with data from three large-scale tracer experiments in North America and Europe (Stohl et al., 1998) and was shown to be capable of simulating intrusions of stratospheric air filaments into the lower troposphere (Stohl and Trickl, 1999; Stohl et al., 2000). It was also used to establish a 15-year climatology of stratospheretroposphere exchange (James et al., 2003) and to study the 
Table 1. Example of an intrusion hit table, issued on 19 June 2001 at 00:00 UTC for Jungfraujoch, based upon ECMWF forecast data for the time period 19-23 June 2001. The intrusion hit table is a matrix of time (time step of 3 hours) versus altitude and contains values of " 0 " and "1", with " 1 " meaning that the air at the respective altitude and time originates in the stratosphere

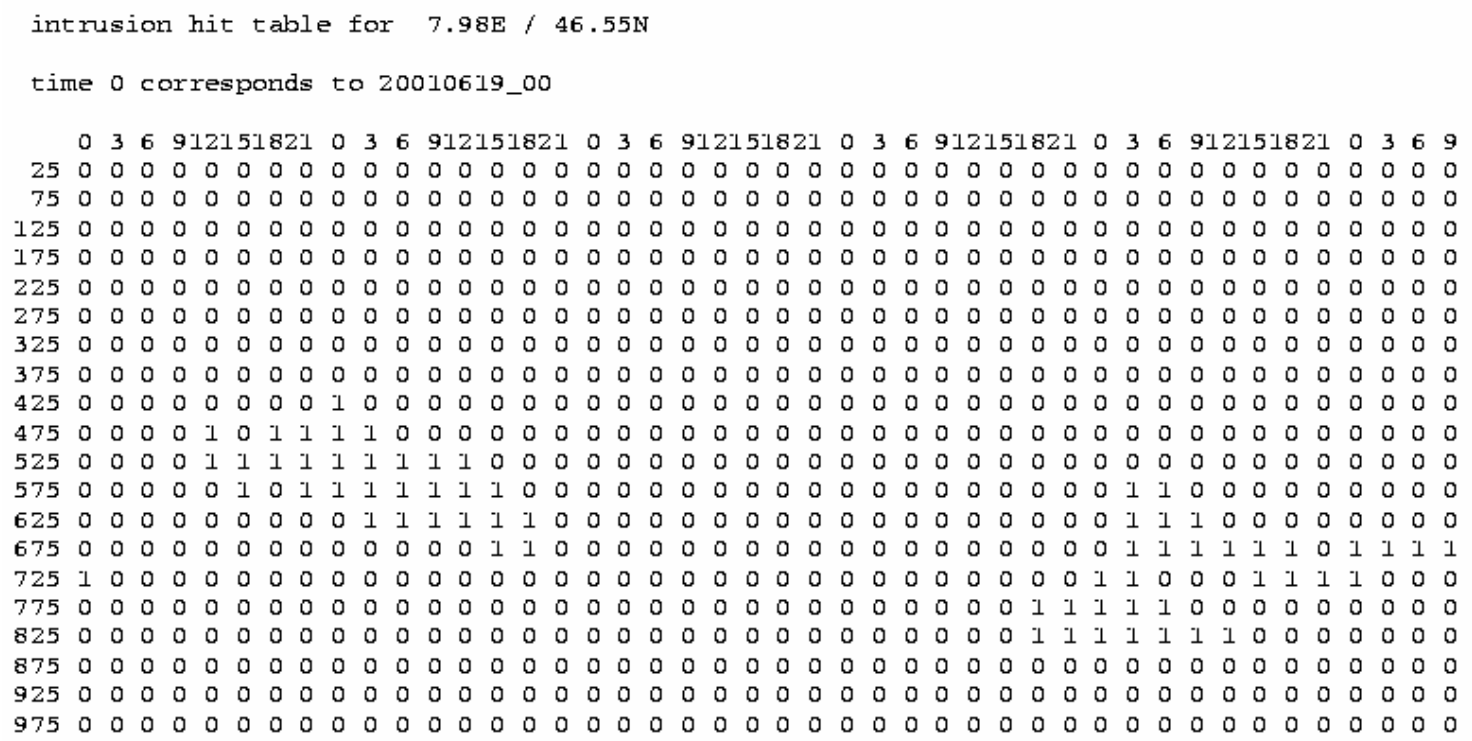

transport of aircraft emissions (Forster et al., 2003). This study contributes to the further validation of FLEXPART.

FLEXPART was driven with global model-level data from the European Centre for Medium-Range Weather Forecasts [ECMWF, 1995] with a horizontal resolution of $1^{\circ}, 60$ vertical levels and a time resolution of $3 \mathrm{~h}$ (analyses at 00:00, 06:00, 12:00, 18:00 UTC; 3-h forecasts at 03:00, 09:00, 15:00, 21:00 UTC). FLEXPART treats advection and turbulent dispersion by calculating the trajectories of a multitude of particles. Stochastic fluctuations of the three wind components are superimposed on the grid-scale winds to represent transport by turbulent eddies. In the boundary layer, magnitude and Lagrangian decorrelation times of these fluctuations are obtained from a detailed parameterisation, and above the boundary layer the turbulent components are set to small values dependent upon the wind shear. To represent convective transport, FLEXPART was equipped with the convection scheme developed by Emanuel and Zivkovic-Rothman (1999). This scheme uses the grid-scale temperature and humidity data and has the advantage of providing a uniform treatment of all types (i.e., shallow to deep) of moist convection. For every model column a displacement matrix is calculated that is translated into displacement probabilities for individual particles.

The model setup is similar to the one described by Stohl et al. (2000) and Stohl and Trickl (1999), but with an extended model domain stretching from $80 \mathrm{~W}$ to $40 \mathrm{E}$ and from 25 $\mathrm{N}$ to $82 \mathrm{~N}$ and up to $16 \mathrm{~km}$ above sea level. This domain was filled homogeneously with particles on 12 June 2001 . Only stratospheric particles were considered; tropospheric ones were removed from the simulation. Whether a particle is stratospheric or not was determined using the dynamical definition of the tropopause based on a threshold value for the potential vorticity (PV) of 2 potential vorticity units (pvu, $1 \mathrm{pvu}=1 \times 10^{-6} \mathrm{~m}^{2} \mathrm{~K} \mathrm{~kg}^{-1} \mathrm{~s}^{-1}$ ). During the 12-day simulation particles were created in the stratosphere at the inflowing boundary, and destroyed at the outflowing boundary. Approximately 4.5 million particles were present at any time during the simulation.

Each particle carries a certain amount of ozone so that initial ozone concentrations follow the relationship with PV: $\mathrm{O}_{3}$ $[\mathrm{ppb}]=\mathrm{S}[\mathrm{ppb} / \mathrm{pvu}] \times \mathrm{PV}[\mathrm{pvu}]($ Danielsen, 1968; Beekmann et al., 1994). Based on ozonesonde data for the lower stratosphere, Stohl et al. (2000) found $\mathrm{S}=60$ (51) ppb/pvu for the month of June (July). Therefore, a value of $\mathrm{S}=$ $55 \mathrm{ppb} / \mathrm{pvu}$ was used here. Ozone is a passive tracer in the model, but is subject to dry deposition at the surface.

Furthermore, this study contributes to validating the ozone fields produced daily from the ECMWF operational atmospheric model. The ECMWF model uses a very simple chemistry parameterisation for ozone (Carriolle and Déqué, 1986) to forecast the further development of ozone, which on the timescales of typical forecasts is determined mostly by transport (for more information on ECMWF ozone forecast see http://www.ecmwf.int/newsevents/training/ meteorological_presentations/html/DA_Dethof/index.htm). Analysis data are produced four times per day at 00, 06, 12 and 18 UTC (http://www.ecmwf.int/services/archive/). To our knowledge, this is the first validation of a chemical tracer that is used operationally in a weather forecast model. 
a)

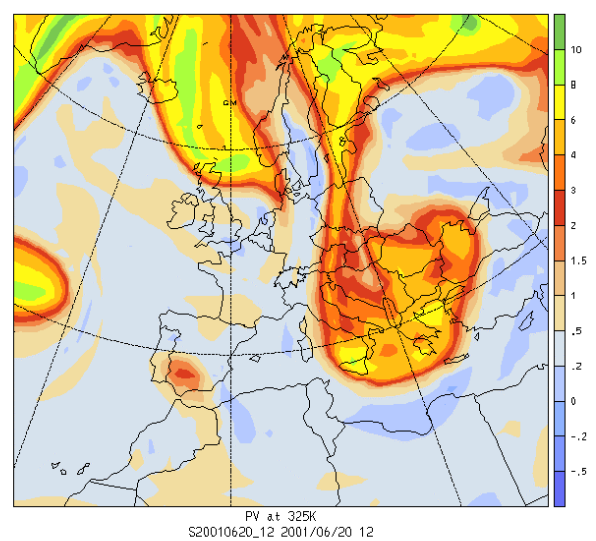

c)

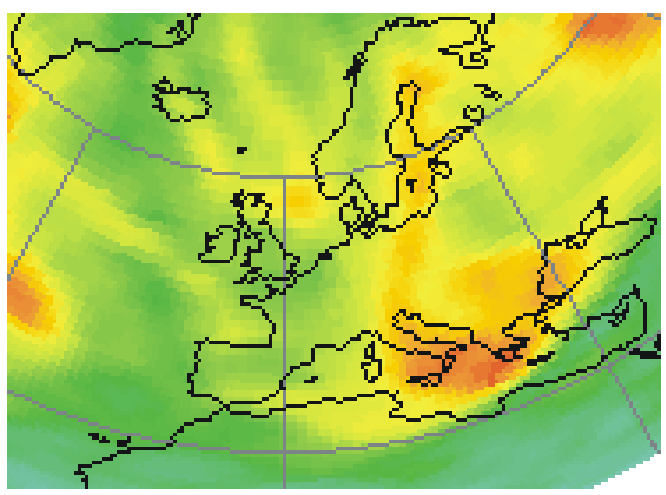

$<150175200225250275300325350375400425460475>500$ DU Assimilated GOME total ozone KNM I/ESA, 20/6/2001 b)

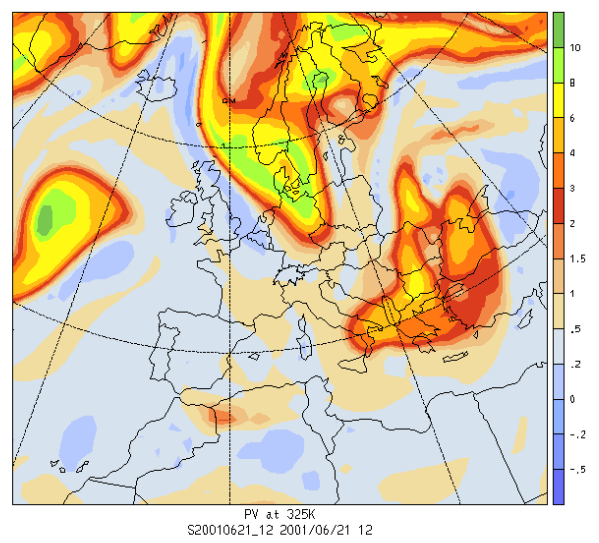

d)

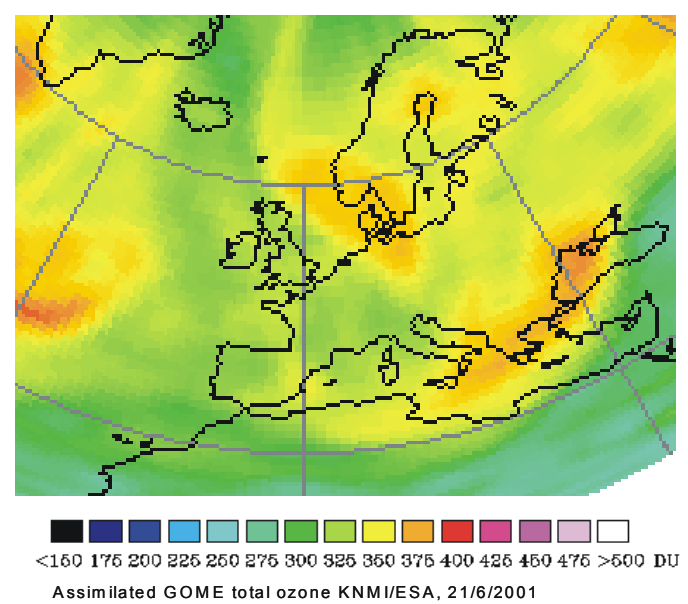

Fig. 2. Isentropic PV on the $325 \mathrm{~K}$ surface on 20 June 2001 12:00 UTC (a) and on 21 June 2001 12:00 UTC (b) based on the ECMWF global analysis data. The assimilated GOME total ozone (KNMI/ESA) fields for 20 June 2001 (c) and 21 June 2001 (d) are additionally shown for comparison with the PV fields.

\section{Results}

\subsection{Description of the synoptic situation}

According to the ECMWF analysis, the synoptic situation on 18 June 2001 was characterized by a deep upper-level trough at $500 \mathrm{hPa}$, extending from Scandinavia to the north of Italy and central Europe. By 19 June 2001 the upper level trough started to detach from the main flow over northern Europe with a large cut-off low developing over southeastern Europe and propagating slowly eastwards during the following two days. On 22 June 2001 the cut-off low re-connected to the main flow over northern Europe, and the upper-level trough gradually dissipated. The development of the synoptic situation is documented in Fig. 2, which shows potential vorticity (PV) on the $325 \mathrm{~K}$ isentropic surface on 20 and 21 June at 12:00 UTC. A hook-shaped streamer of high PV values extended southwards and turned cyclonically on 20 June (Fig. 2a). This high- streamer broke up on 21 June and part of it rolled up in the developing cut-off low (Fig. 2b). On 21
June a second high-PV feature approached central Europe from the north/north-west. The evolution of this upper-level feature is also evident in the respective GOME total column ozone measurements. The GOME total ozone maps show high values on 20 June (Fig. 2c) resembling the hook-shaped streamer of high PV on 20 June while the high total ozone values on 21 June (Fig. 2d) are clearly associated with the developed cut-off low over southeastern Europe.

A consistent view of the stratospheric streamer of high PV and low humidity on 20 and 21 June is also obtained from the METEOSAT geostationary water vapour (WV) images (Figs. $3 \mathrm{a}$ and $3 \mathrm{~b}$ ), that are very useful in depicting the spatial extension of tongues of dry stratospheric air penetrating into the troposphere (Appenzeller et al., 1996b; Cooper et al, 2001; Wimmers et al., 2003). Figures 3a and b, which represent the temperature $(\mathrm{K})$ of the top layer of $\mathrm{WV}$ in the atmosphere, indicate a streamer of dry air extending southwards on 20 June (at 12:00 UTC) and being detached on 21 June (at 12:00 UTC) that coincides with the development of the stratospheric streamer in Figs. 2a and b. The PV on 


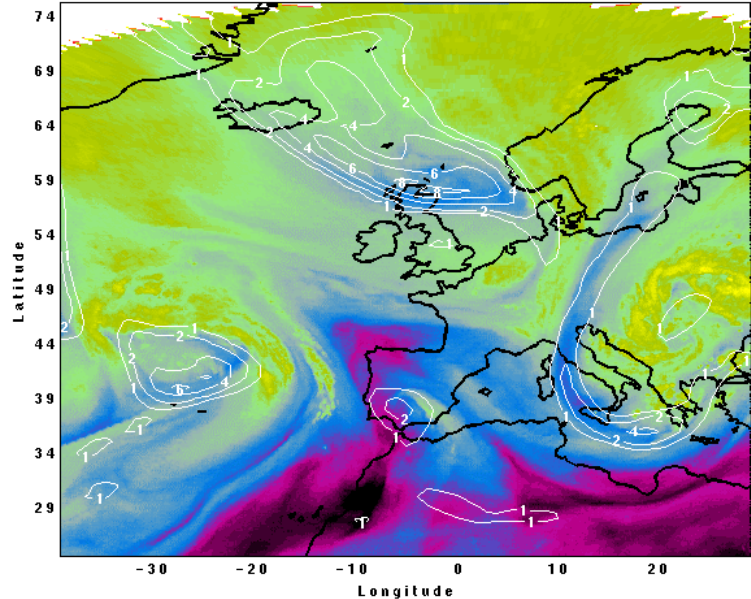

200205210215220225230235240245250255260265

a)

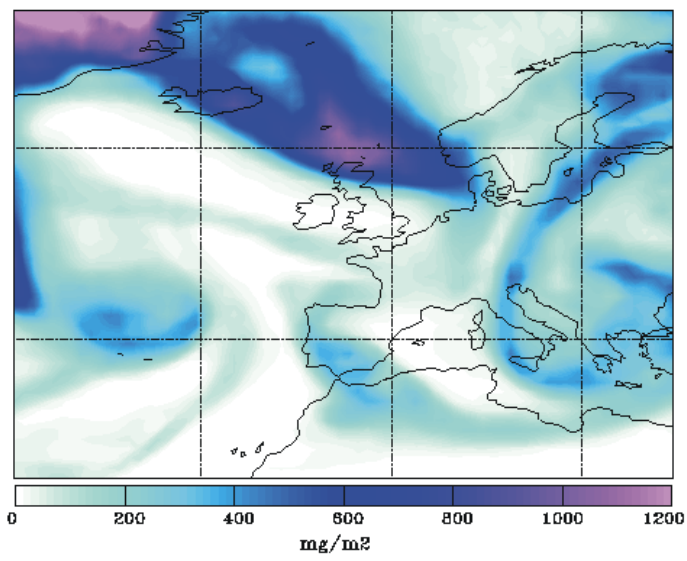

c)

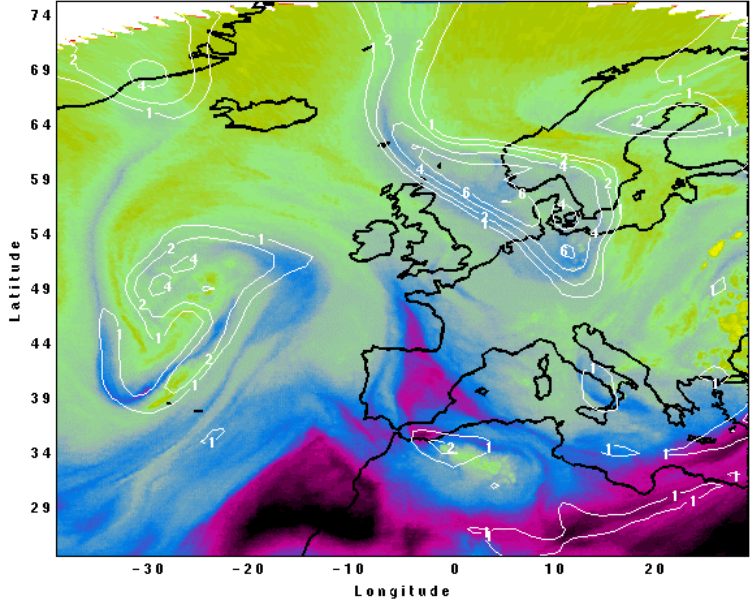

200205210215220225230235240245250255260265

b)

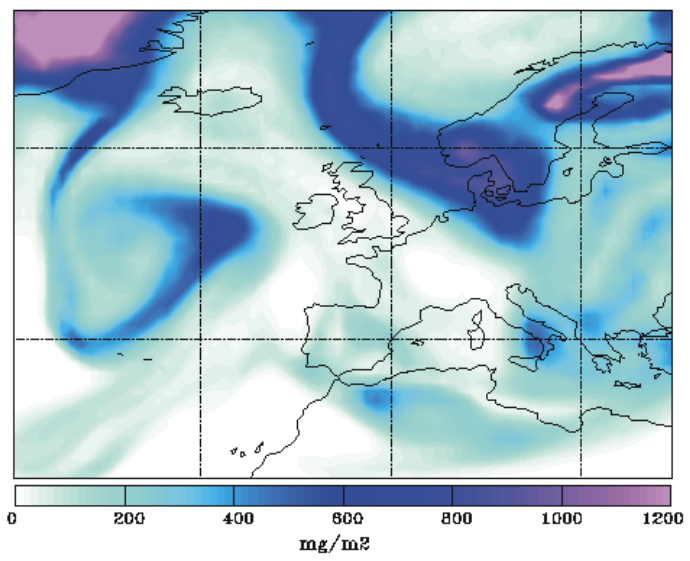

d)

Fig. 3. WV images on 20 June at 12:00 UTC (a) and on 21 June 12:00 UTC (b). The colour scale represents the temperature (K) of the top layer of WV in the atmosphere. The PV on the $350 \mathrm{hPa}$ surface calculated from the NCEP AVN data is marked in Figs. 3a and b with white contours in pvu. The ozone tracer columns between 5500 and $11000 \mathrm{~m}$ on 20 June at 12:00 UTC (c) and on 21 June 12:00 UTC (d), calculated from the FLEXPART model, are illustrated for comparison with the observations of WV.

the $350 \mathrm{hPa}$ isobaric surface in Figs. $3 \mathrm{a}$ and b was calculated from the NCEP AVN data at $1 \times 1$ degree horizontal grid spacing and $50 \mathrm{hPa}$ vertical grid spacing. Thus, Figs. 3a and $b$ clearly indicate that air of stratospheric origin characterised with high PV and very low WV penetrates into the troposphere over central and southeastern Europe. The WV images from the previous days indicate that this streamer of dry air was present since 18 June 2001, initially located over western Europe extending from Belgium and Holland to southern France and gradually moving eastwards over central Europe and southeastern Europe. The WV images in Figs. 3a and $b$ compare well with the tracer simulation of the FLEX-
PART model of the ozone tracer column between 5500 and $11000 \mathrm{~m}$ in Figs. 3c and d (see Sect. 3.4 for further discussion).

The vertical distribution of the high-PV streamer on 20 June is illustrated by the W-E oriented vertical cross-sections of PV and RH over Jungfraujoch on 20 June at 12:00 UTC, based on the ECMWF analyses (Fig. 4a). They show a tongue of high PV values associated with low RH. The PV values within the tongue range from 0.5 to 1.5 pvu suggesting mixing of stratospheric air ( $\mathrm{PV}>2 \mathrm{pvu}$ ) with tropospheric air or other diabatic effects such as radiative erosion of PV. Ozone fields are analysed and forecast operationally along 

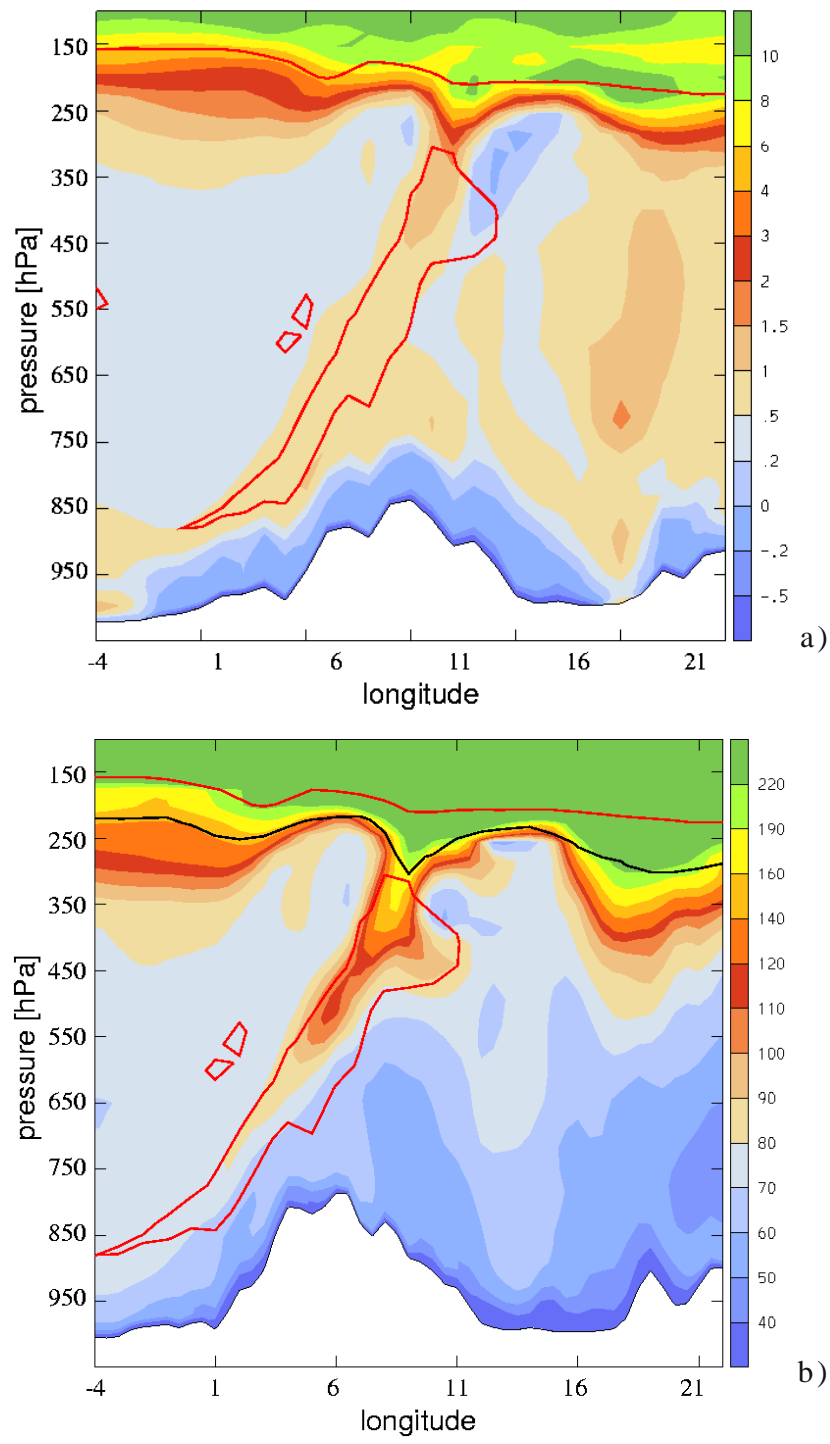

Fig. 4. W-E oriented vertical cross-sections of PV (a) and ozone (b) over Jungfraujoch on 20 June at 12:00 UTC, based on the ECMWF global analysis data. The red line indicates low RH (15\%) while the black line in $\mathrm{b}$ ) indicates the dynamical tropopause ( $\mathrm{PV}=2 \mathrm{pvu})$. The W-E oriented vertical cross section of PV at the latitude of Jungfraujoch (46.53 N, 7.98 E) ranges from $4 \mathrm{~W}$ to $26 \mathrm{E}$.

with the meteorological parameters at ECMWF since October 1999. Figure 4b, which shows the ECMWF ozone fields along the same cross-section, clearly indicates an intrusion of stratospheric air rich in ozone down to the lower free troposphere that is correlated with the tongue of low RH and, in the upper part, elevated PV values. As the air penetrates deeper in the troposphere, ozone decreases from about 100 $120 \mathrm{ppbv}$ at $450 \mathrm{hPa}$ to about $80-90 \mathrm{ppbv}$ at $650-700 \mathrm{hPa}$.

\subsection{Profile observations}

The profile measurements of ozone and RH at several stations within the dry streamer area provide observational evidence that stratospheric air penetrated deep into the troposphere. The ozonesonde and radiosonde measurements at Uccle, Belgium (50.8 N, 4.35 E) Payerne, Switzerland (46.49 $\mathrm{N}, 6.57 \mathrm{E})$ and Hohenpeienberg, Germany (47.8 N, 11.0 E) on 18 and 20 June 2001 provided snapshots of the vertical distribution of ozone and RH indicating dry layers rich in ozone (Fig. 5). An ozonesonde was launched from Uccle, into the dry streamer at 11:00 UTC 18 June, detecting a layer between 500 and $400 \mathrm{hPa}$ with ozone values up to 140 ppbv and RH less than $10 \%$ (Fig. 5a), while on 20 June (at 11:00 UTC) two dry layers (RH at about 20\%) were measured with ozone up to 80 and $90 \mathrm{ppbv}$ at about 600 and $500 \mathrm{hPa}$, respectively (Fig. 5b). All these layers may be ascribed to the two major intrusions described above. At Payerne, there is a minor peak of ozone up to $80 \mathrm{ppbv}$ at $500 \mathrm{hPa}$ on 18 June at 11:00 UTC (Fig. 5c), but on 20 June a large ozone peak up to $90 \mathrm{ppbv}$ is revealed in the lower free troposphere down to $650 \mathrm{hPa}$ (at 11:00 UTC) associated with very dry air $(\mathrm{RH}<20 \%)$ (Fig. $5 \mathrm{~d})$. At Hohenpeienberg, minor structures are seen on 18 June (at 05:00 UTC), but on 20 June (at 05:00 UTC) a very prominent peak of ozone up to $140 \mathrm{ppb}$ (see Uccle) is captured at $400 \mathrm{hPa}$ associated with very dry air $(\mathrm{RH}<20 \%)$ (Fig. 5f). The peak at Hohenpeienberg on 20 June is higher up compared to the ozone peak at $650 \mathrm{hPa}$ at Payerne but the launch time of the ozonesonde was 6 hours earlier.

The radiosonde profiles at San Pietro Capofiume (not shown here), which is located close to Mt. Cimone in northern Italy, indicate a very dry layer $(\mathrm{RH}<10 \%)$ between 500 and $600 \mathrm{hPa}$ at 00:00 UTC on 21 June while 12 hours later a very dry layer is located between 700 and $600 \mathrm{hPa}$. Finally, the radiosonde profiles at Thessaloniki (not shown here) indicate very dry air $(\mathrm{RH}<10 \%)$ between 4 and $6 \mathrm{~km}$ on 23 June 2001 at 06:00 and 12:00 UTC, but not on the previous days.

The ozone lidar measurements are extremely valuable because they have the advantage of providing continuous ozone profile measurements, which may capture the evolution of an intrusion event. The time-height-plot of the ozone lidar measurements at Garmisch-Partenkirchen, Germany, on 20-21 June 2001 captures the evolution of a rather complex episode with two marked tongues of elevated ozone with almost 150 ppbv shortly after the beginning of the measurements and a minor isolated structure with elevated ozone (Fig. 6a). This minor isolated structure with elevated ozone is observed at $3 \mathrm{~km}$ and horizontally intersected the Zugspitze summit on 20 June, which is characterized by relative humidity values around $28 \%$ and a peak ozone mixing ratio of around $70 \mathrm{ppb}$ (see Fig. 7a), in agreement with the lidar measurements. The meteorological analysis indicates that the observed tongue of elevated ozone is not an intrusion actively descending over Garmisch but the horizontal advection (west 

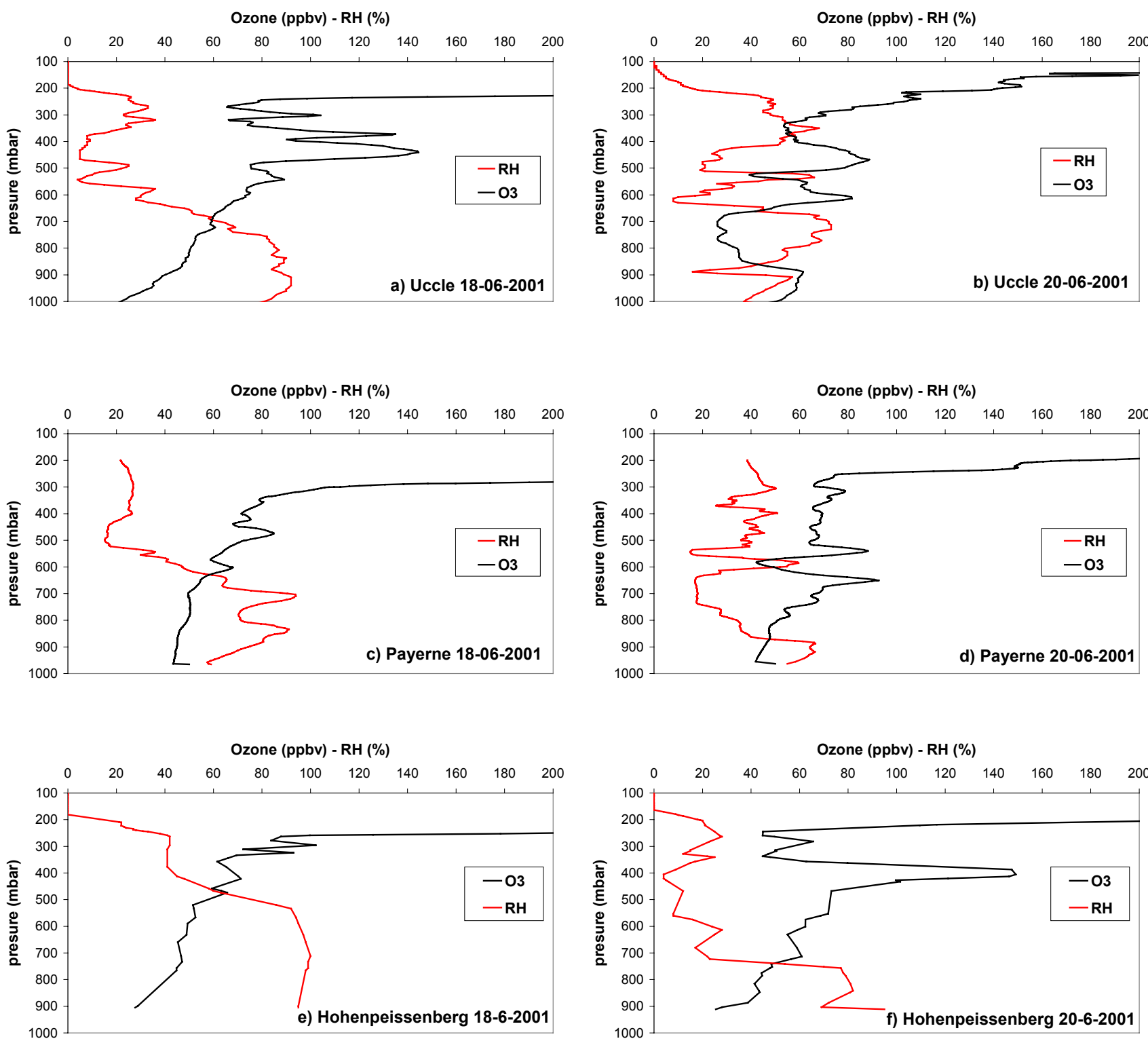

Fig. 5. Profile measurements of ozone and RH based on ozonesonde launches on 18 and 20 June 2001 at Uccle (a and b) at 11:00 UTC, at Payerne (c and d) at 11:00 UTC and at Hohenpeißenberg (e and f) at 05:00 UTC.

to east) of a pre-existing sloped feature as shown in Fig. 4. The faster the horizontal advection, the faster the apparent descent. The first marked tongue could be traced with the lidar over an exceptional vertical range from almost $8 \mathrm{~km}$ down to about $2 \mathrm{~km}$ a.s.l. This tongue is characterised by a gradual decrease of ozone as it penetrates deeper into the troposphere, possibly due to dilution. For example, ozone is $145 \mathrm{ppbv}$ at $7.1 \mathrm{~km}$ (in excellent agreement with the sonde results), about $84 \mathrm{ppbv}$ at $4.3 \mathrm{~km}$ after 16 hours, and then $71 \mathrm{ppbv}$ at $3.0 \mathrm{~km}$ after the next 6 hours (Fig. 6a). The model simulations (Sect. 3.4, Figs. 6b and c) suggest that the lidar missed the beginning of the folding event by just a few hours and that the lidar almost looked into the stratosphere at the beginning of the observational period. Of special interest are the two steep downward steps in the lidar data at about 18:00 UTC (June 20) and 06:00 UTC (June 21), which contrast with the deceleration of the subsidence in the lower troposphere as shown in Plate 2 in Stohl and Trickl (1999) These steps are nicely reproduced by the FLEXPART model simulation (Fig. 6b, see Sect. 3.4). The second sloped feature started to form in the uppermost troposphere at about midnight between June 20 and 21 and was followed by the lidar down to almost $4 \mathrm{~km}$ (see Sect. 3.1, Figs. 2 and 3). This is the first case in which a tropopause fold could be observed with the IFU lidar from its inception. 
June 20 and 21, 2001

a)

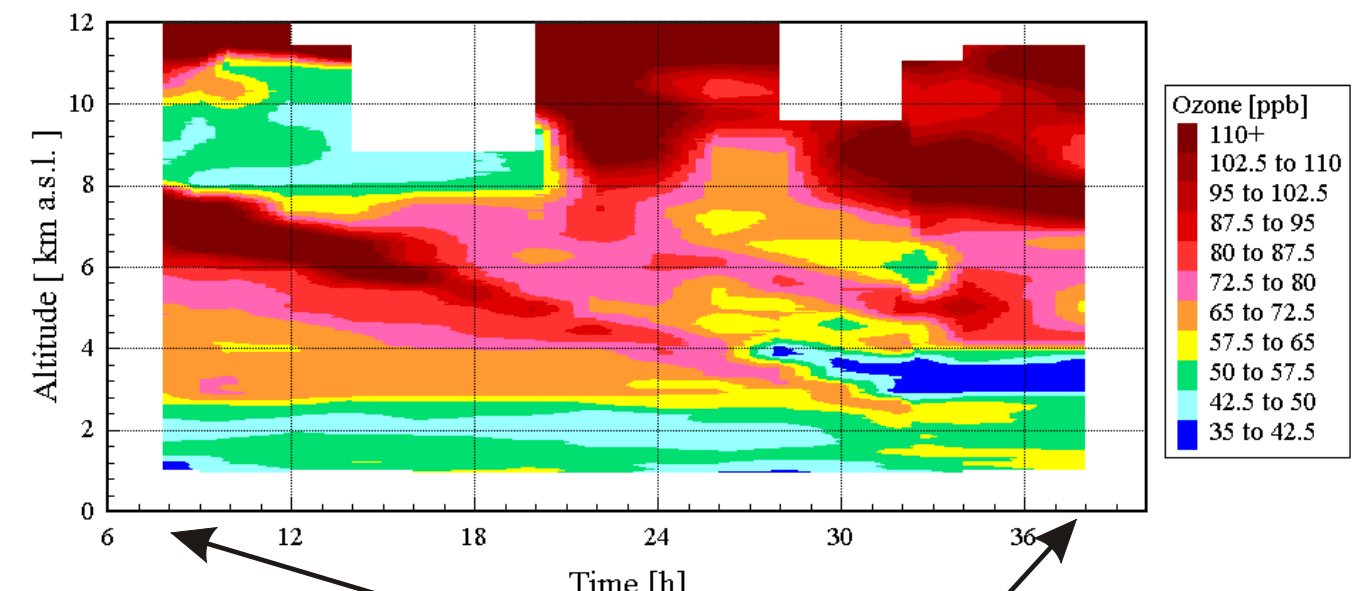

b)

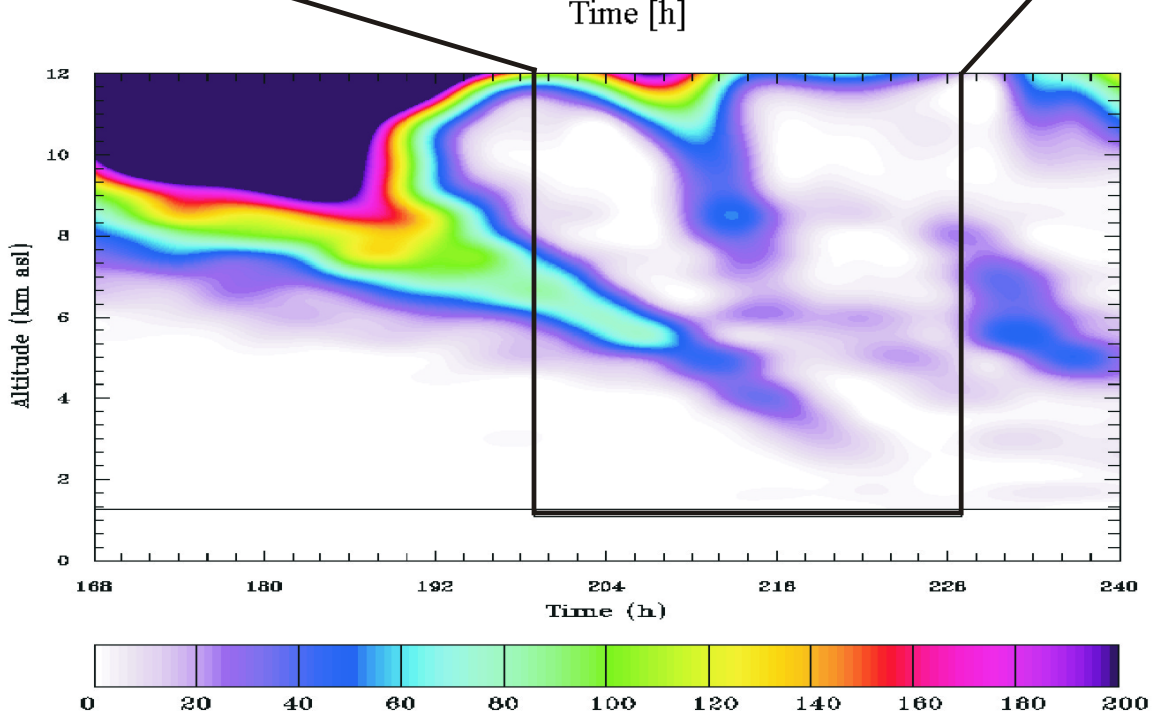

c)

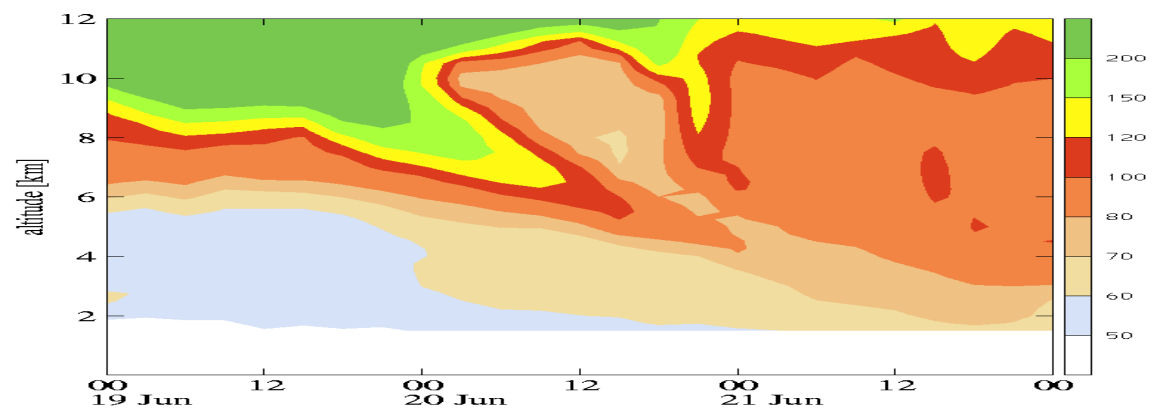

Fig. 6. (a) Time-height section of the ozone lidar measurements at Garmisch-Partenkirchen during 20 and 21 June (Central European Time $(\mathrm{CET}),=\mathrm{UTC}+1 \mathrm{~h})$. (b) Time-height section through the FLEXPART ozone tracer field at the location of Garmisch-Partenkirchen. Time is given in hours from the start of the simulation; the plot covers the period from 19 June 00:00 UTC to 22 June 00:00 UTC. The black rectangle marks the period and altitude range of the lidar measurements. The horizontal line shows the height of the model topography. (c) Time-height section through the ECMWF ozone field at the location of Garmisch-Partenkirchen for the period from 19 June 00:00 UTC to 22 June 00:00 UTC. 
Table 2. Summary statistics of ${ }^{7} \mathrm{Be},{ }^{10} \mathrm{Be}$ and their ratio at Zugspitze and Jungfraujoch during 2000 and 2001.

\begin{tabular}{|c|c|c|c|c|c|c|}
\hline & \multicolumn{3}{|c|}{ ZUG } & \multicolumn{3}{|c|}{ JFJ } \\
\hline & $\begin{array}{c}{ }^{7} \mathrm{Be} \\
\left(10^{4} \times \text { atoms } / \mathrm{m}^{3}\right)\end{array}$ & $\begin{array}{c}{ }^{10} \mathrm{Be} \\
\left(10^{4} \times \text { atoms } / \mathrm{m}^{3}\right)\end{array}$ & ${ }^{10} \mathrm{Be} /{ }^{7} \mathrm{Be}$ & 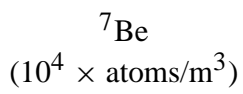 & $\begin{array}{c}{ }^{10} \mathrm{Be} \\
\left(10^{4} \times \text { atoms } / \mathrm{m}^{3}\right)\end{array}$ & ${ }^{10} \mathrm{Be} /{ }^{7} \mathrm{Be}$ \\
\hline Median & 3.2 & 5.3 & 1.8 & 3.6 & 6.8 & 2.0 \\
\hline 1st quart. & 1.8 & 3.3 & 1.5 & 2.5 & 5.0 & 1.6 \\
\hline 3rd quart. & 4.5 & 7.4 & 2.1 & 4.9 & 10.2 & 2.4 \\
\hline Min & 0.06 & 0.1 & 0.7 & 0.5 & 0.5 & 1 \\
\hline Max & 10.4 & 19.1 & 3.5 & 11.7 & 29.7 & 3.7 \\
\hline Numb. of samples & & 167 & & & 110 & \\
\hline
\end{tabular}

\subsection{Surface observations}

The surface measurements of humidity, ozone and the cosmogenic radionuclides ${ }^{7} \mathrm{Be}$ and ${ }^{10} \mathrm{Be}$ at the Alpine peak stations of Jungfraujoch and Zugspitze show that the stratospheric intrusion was, indeed, detectable down to $3000 \mathrm{~m}$. At Zugspitze, there is clear evidence that the intrusion reached that height as RH decreased to $20 \%$ on 20 and 21 June, while ozone rose from 52 to $69 \mathrm{ppbv}$ on 20 June and 58 to $71 \mathrm{ppbv}$ on 21 June (Fig. 7a), in agreement with the nearby lidar measurements. The daily ${ }^{7} \mathrm{Be}$ activity concentrations increased from near the detection limit of $0.1 \mathrm{mBq} / \mathrm{m}^{3}\left(591\right.$ atoms $\left./ \mathrm{m}^{3}\right)$ on 18 and 19 June to $7.6 \mathrm{mBq} / \mathrm{m}^{3}\left(5.0 \times 10^{4}\right.$ atoms $\left./ \mathrm{m}^{3}\right)$ on 20 June and remained at these high levels for several days. Precipitation data (not shown here) indicate no precipitation from 20 to 26 June, while on 18 and 19 June there was precipitation (maximum of the whole month on 18th June) resulting possibly in the low daily ${ }^{7} \mathrm{Be}$ concentrations due to wet scavenging. Table 2 shows summary statistics of the ${ }^{7} \mathrm{Be}$ and ${ }^{10} \mathrm{Be}$ measurements at Zugspitze and Jungfraujoch during 2000 and 2001 for comparison purposes. The daily ${ }^{10} \mathrm{Be}$ activity concentrations measured on 20,21 and 22 June also remain at rather high levels, ranging from about $8.5 \times 10^{4}$ to $9.2 \times 10^{4}$ atoms $/ \mathrm{m}^{3}$. Although there are no ${ }^{10} \mathrm{Be}$ measurements on the previous days, the ${ }^{10} \mathrm{Be}$ measurements during 20,21 , and 22 June are among the highest $25 \%$ of all the ${ }^{10} \mathrm{Be}$ measurements at Zugspitze (see Table 2). The ratios of ${ }^{10} \mathrm{Be} /{ }^{7} \mathrm{Be}$, which is a stratospheric tracer not affected by washout, remain rather constant on 20, 21 and 22 June, ranging from 1.71 to 1.90 (3rd quartile $=2.1$ in Table 2). Jordan et al. (2003), using aircraft samples in both the stratosphere and troposphere reported the absence of ratios $<1.27$ in the lowermost stratosphere indicating that ratios observed in the troposphere, nearer their production ratio of 0.60 , are characteristic of tropospheric air with minimal stratospheric influence. So the ratio measurements at Zugspitze during this case study, even though they are not among the highest recorded during 2000 and 2001 imply stratospheric influence.

At Jungfraujoch, there is also clear observational evidence that the intrusion reached that height as RH decreased to $20 \%$ on 20 June, while ozone rose from 60 up to 85 ppbv (Fig. 7b). The dry layers arrived slightly earlier than at Zugspitze due to a more western location. The ozone increase at Jungfraujoch on 20 June is in agreement with the ozone profile data at Payerne on 20 June which show an ozone peak at $650 \mathrm{hPa}$ or about $3500 \mathrm{~m}$ asl (Fig. 5d). Back trajectory analysis (not shown here) below, at the same level, and above Jungfraujoch on 12:00 and 18:00 UTC indicates that air masses descended from about 300 and $400 \mathrm{hPa}$ over the north Atlantic region down to 650 and $700 \mathrm{hPa}$.

However, the bi-daily ${ }^{7} \mathrm{Be}$ activity concentrations decrease from about $7.5 \mathrm{mBq} / \mathrm{m}^{3}\left(4.9 \times 10^{4}\right.$ atoms $\left./ \mathrm{m}^{3}\right)$ on $18-19$ June to $2.1 \mathrm{mBq} / \mathrm{m}^{3}\left(1.4 \times 10^{4}\right.$ atoms $\left./ \mathrm{m}^{3}\right)$ on $20-21$ June. Similarly, the bi-daily ${ }^{10} \mathrm{Be}$ activity concentrations decrease from about $12.7 \times 10^{4}$ atoms $/ \mathrm{m}^{3}$ on $18-19$ June to $4.5 \times$ $10^{4}$ atoms $/ \mathrm{m}^{3}$ on $20-21$ June. The ${ }^{7} \mathrm{Be}$ and ${ }^{10} \mathrm{Be}$ activity concentrations on 20-21 June are among the lowest $25 \%$ of all the ${ }^{7} \mathrm{Be}$ and ${ }^{10} \mathrm{Be}$ measurements carried out at Jungfraujoch during the years 2000 and 2001, respectively (see Table 2). These low ${ }^{7} \mathrm{Be}$ and ${ }^{10} \mathrm{Be}$ activity concentrations on 20-21 June could be possibly attributed to wet scavenging but there are no precipitation data to prove this possibility. The ${ }^{10} \mathrm{Be} /{ }^{7} \mathrm{Be}$ ratios stay at high levels on all days, and are among the highest $25 \%$ of all the ${ }^{10} \mathrm{Be} /{ }^{7} \mathrm{Be}$ values measured at Jungfraujoch during the years 2000 and 2001 (3rd quartile $=2.4$ in Table 2). The ratio reaches its maximum of 3.2 on 18-19 June although in contrast the independent ${ }^{7} \mathrm{Be}$ and ${ }^{10} \mathrm{Be}$ concentrations are very low, thus providing possible evidence that during occasions of wet scavenging the ${ }^{10} \mathrm{Be} /{ }^{7} \mathrm{Be}$ ratio can still be a valid stratospheric tracer although ${ }^{7} \mathrm{Be}$ and ${ }^{10} \mathrm{Be}$ are not. Nevertheless these results should be considered with caution because the very low time resolution of the measurements at Jungfraujoch (bi-daily samples), which is long compared to the typical duration of a stratospheric influence, is a limiting factor.

\subsection{FLEXPART and ECMWF model calculations}

At upper tropospheric levels, the tracer simulation of the FLEXPART model with the ozone tracer column between 5500 and $11000 \mathrm{~m}$ (FigS. 3c and d) can be compared to the WV images (Figs. 3a and b). Although such a comparison is not quantitative, structures seen in the tracer column should coincide with dry regions in the WV images. However, 

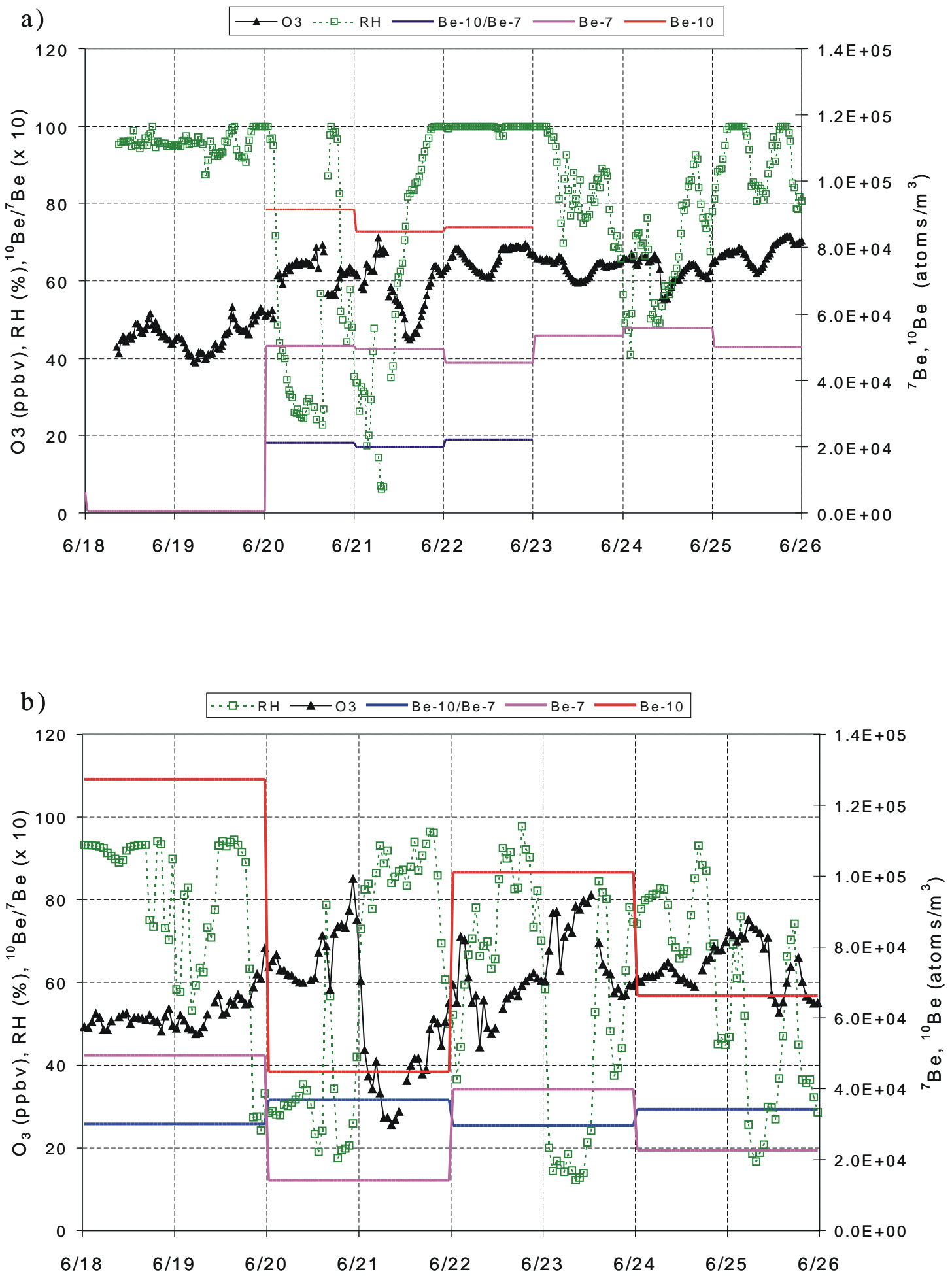

Fig. 7. Surface measurements of RH, ozone, ${ }^{7} \mathrm{Be},{ }^{10} \mathrm{Be}$ concentrations and their ratio ${ }^{10} \mathrm{Be} /{ }^{7} \mathrm{Be}$ at Zugspitze (a) and at Jungfraujoch (b), during the period $18-25$ June 2001 ; the time is CET. The ${ }^{7} \mathrm{Be},{ }^{10} \mathrm{Be}$ concentrations and their ratio are daily values at Zugspitze and bi-daily at Jungfraujoch. 
if moist air lies above the dry intrusion, the latter may be masked from the satellite's view and thus some structures may be missing in the WV images. As the tracer plots are 3-h averages, tracer structures are smoothed and may show less fine-scale structure than the WV images. The ozone tracer columns between 5500 and $11000 \mathrm{~m}$ on 20 June and 21 June at 12:00 UTC, illustrated in Figs. 3c and d, are in very good agreement with the WV images (Figs. 3a and b), resembling in space the streamer of dry air with high PV values on the $350 \mathrm{hPa}$ surface extending southwards.

The time-height cross-section of the FLEXPART ozone tracer over Garmisch-Partenkirchen is compared with the respective time-height cross section of ozone retrieved from the IFU lidar measurements (Fig. 6a). The FLEXPART ozone tracer time-height section (Fig. 6b) shows two separate tongues of stratospheric ozone descending into the troposphere, separated by a region without stratospheric tracer. The ozone tracer maximum descending down to below $4 \mathrm{~km}$ corresponds well with the high-ozone filament seen in the lidar data, and the smaller tongue of maximum ozone tracer in the middle of the observation period corresponds with the observed ozone maximum at an altitude of approximately $10 \mathrm{~km}$ on 20 June at 22:00 UTC. Both are clearly separated by ozone mixing ratios below $50 \mathrm{ppbv}$, which are typical of the troposphere. The ozone maxima observed at the end of the measurement period at $5 \mathrm{~km}$ and $8 \mathrm{~km}$ are not present in the model simulation, but a tracer maximum is seen just after the end of the observations. Generally, FLEXPART slightly underestimates the observed ozone mixing ratios within the stratospheric filaments, possibly due to a too low $\mathrm{O}_{3}-\mathrm{PV}$ relationship used in the initialisation, the neglect of tropospheric $\mathrm{O}_{3}$ and the insufficient vertical resolution. However, the most important structures such as the two steps mentioned in Sect. 3.2 are well represented, confirming the stratospheric nature of the two observed high-ozone filaments and demonstrating the considerable quality with which FLEXPART captures the details.

Furthermore the time-height cross section of ozone retrieved from the IFU lidar measurements provides an excellent opportunity to validate the ECMWF ozone which is a newly available product analysed and forecast operationally along with the meteorological parameters at ECMWF since October 1999. The ECMWF ozone time-height section over Garmisch-Partenkirchen during the same event (Fig. 6c) captures successfully the two separate tongues of stratospheric ozone descending through the troposphere down to $4 \mathrm{~km}$. Although the minor structures found in the lidar measurements cannot be seen in ECMWF ozone due to the coarse resolution of the ECMWF model, the most important features, however, compare very well with the lidar observations even though the $\mathrm{O}_{3}$ chemistry in the ECMWF model is only represented in a simplified way. This suggests that coupling chemistry and weather forecast models may significantly improve both weather and chemical forecasts in the future. To our knowledge, this is the first validation of a chemical tracer that is used operationally in a weather forecast model. At the time of our case study, ozone observations were not yet assimilated into the ECMWF model. With the assimilation of ozone observations, which was started only recently (A. Hollingsworth, personal communication), the agreement would perhaps have been even better. Even more so, the quality of the ECMWF ozone data in this case is surprising. It should be pointed that Roelofs et al. (2003) compared results from 6 global tropospheric chemistry models with the lidar observations of ozone during the same deep STT event and it was found that all models qualitatively captured the deep intrusion of stratospheric air, however the models with coarse vertical resolution suffered from numerical diffusion and thus overestimated the transport of stratospheric ozone into the troposphere, and transported it too close to the ground.

\section{Conclusions}

In order to cover a substantial amount of stratospheric intrusions within the framework of the EU-project STACCATO, co-ordinated measurements during short campaigns were carried out based on forecast trajectories. These stratospheric intrusion forecasts aided the measurement groups with the set-up and planning of the observations. One of the forecast STE events encountered during the STACCATO period was followed by the measurements network from its inception, providing clear observational evidence of a complex deep stratospheric intrusion event. Both this case study and other events that were succesfully forecast during STACCATO (Galani et al., 2003) proved that these STE forecasts are valuable in planning co-ordinated measurements.

The ozone tracer columns calculated with the FLEXPART model were found to be in good agreement with water vapour satellite images, capturing the evolution of the observed dry streamers of stratospheric origin. In addition, to the best of our knowledge, the first concurrent surface measurements of the cosmogenic radionuclides ${ }^{10} \mathrm{Be}$ and ${ }^{7} \mathrm{Be}$ and their ratio ${ }^{10} \mathrm{Be} /{ }^{7} \mathrm{Be}$ are presented in a case study of a stratospheric intrusion. At Zugspitze, the ${ }^{10} \mathrm{Be} /{ }^{7} \mathrm{Be}$ ratio values indicated stratospheric influence during this case study, even though these values were not among the highest ones recorded during 2000 and 2001 at the site. At Jungfraujoch, the ${ }^{10} \mathrm{Be} /{ }^{7} \mathrm{Be}$ ratio reached its maximum value of 3.2 on $18-19$ June although in contrast the independent ${ }^{7} \mathrm{Be}$ and ${ }^{10} \mathrm{Be}$ concentrations were very low thus implying that in occasions of wet scavenging the ${ }^{10} \mathrm{Be} /{ }^{7} \mathrm{Be}$ ratio can still be a valid stratospheric tracer although ${ }^{7} \mathrm{Be}$ and ${ }^{10} \mathrm{Be}$ cannot. Nevertheless these results should be considered with caution because the low time resolution of the measurements at Jungfraujoch (bidaily samples) and at Zugspitze (daily samples), which can be long compared to the time period of a stratospheric influence, is a limiting factor.

Among the considerable amount of data providing the observational evidence for the presented STT event, the ozone 
lidar observations at Garmisch-Partenkirchen should be emphasised as they captured the evolution of the descending filaments down to almost $2 \mathrm{~km}$ over Garmisch. This excellent data set was used to validate the FLEXPART model and also for the first time the ECMWF ozone, a recently available product analysed and forecast operationally along with the meteorological parameters since October 1999. Generally, FLEXPART slightly underestimated the observed ozone concentrations within the stratospheric filaments, possibly due to a too low $\mathrm{O}_{3}-\mathrm{PV}$ relationship used in the initialisation and the insufficent vertical resolution however, the most important structures were well represented thus demonstrating the capabilities of FLEXPART in capturing details. Finally, the ECMWF ozone product gave a correct picture of the event with the most important features in good agreement with the lidar observations even though the $\mathrm{O}_{3}$ chemistry in the ECMWF model is only represented in a simplified way, suggesting that coupling chemistry and weather forecast models may significantly improve both weather and chemical forecasts in the future.

Acknowledgements. This study was carried out within STACCATO (Contract No. EVK2-CT1999-00050), a project funded by the European Commission under the Fifth Framework Programme. We also thank the Swiss Meteorological Institute (SMI) at Payerne for providing the ozonesonde data. ECMWF and Deutscher Wetterdienst are acknowledged for providing access to the ECMWF archives. Meteosat water vapour images were provided by Space Science and Engineering Center, University of Wisconsin-Madison. The work by IFU and TUM was also funded by the German Bundesministerium fr Bildung und Forschung (BMBF) within the ATMOFAST project. The sampling and delivery of the air filter samples from Jungfraujoch was carried out by EMPA, Dübendorf, Switzerland. Relative humidity data for the Jungfraujoch were provided by Meteo Schweiz, Kundendienst Bodendaten, Zurich. We thank the Swiss Agency for the Environment, Forests and Landscape, BUWAL, for the ozone data measured at the Jungfraujoch. This work was also funded in part by the Bundeamt fuer Bildung und Wissenschaft, BBW, Berne, Switzerland.

\section{References}

Ancellet, G., Pelon, J., Beekmann, M., Papayannis A., Megie G.: Ground-based lidar studies of ozone exchanges between the stratosphere and the troposphere, J. Geophys. Res., 96(D12), 22 401-22 421, 1991.

Appenzeller, C., Holton, J. R., and Rosenlof, K. H.: Seasonal variation of mass transport across the tropopause, J. Geophys. Res., 101(D10), 15 071-15078, 1996 .

Appenzeller, C., Davies, H. C., and Norton, W. A.: Fragmentation of stratospheric intrusions, J. Geophys. Res., 101(D1), 14351456, 1996b.

Austin, J. F. and Follows, M. J.: The ozone record at Payerne: An assessment of the cross-tropopause flux. Atmos. Environ., 25A(9), 1873-1880, 1991.

Beekmann, M., Ancellet, G., and Mégie, G.: Climatology of tropospheric ozone in southern Europe and its relation to potential vorticity, J. Geophys. Res. 99, 12 841-12 853, 1994.
Browell, E. V., Ismail, S., and Grant, W. B.: Differential absorption lidar (DIAL) measurements from air and space, Appl. Phys. B 67, 399-410, 1998.

Carriolle, D. and Déqué, M.: Southern hemisphere medium-scale waves and total ozone disturbances in a spectral general circulation model, J. Geophys., Res., 91(D10), 10 825-10 846, 1986.

Chameides, W. and Walker, J. C. G.: A photochemical theory of tropospheric ozone, J. Geophys. Res., 78(36), 8751-8760, 1973.

Cooper, O. R., Moody, J. L., Davenport, J. C., Oltmans, S. J., Johnson, B. J., Chen, X., Shepson, P. B., and Merrill, J. T.: The influence of springtime weather systems on vertical ozone distributions over three North American sites, J. Geophys. Res., 103, 22 001-22 013, 1998.

Cooper, O. R., Moody, J. L., Parrish, D. D., Trainer, M., Holloway, J. S., Ryerson, T. B., Hübler, G., Fehsenfeld, F. C., Oltmans, S. J., and Evans, M. J.: Trace gas signatures of the airstreams within North Atlantic cyclones - Case studies from the NARE'97 aircraft intensive, J. Geophys. Res., 106, 5437-5456, 2001.

Crutzen, P. J.: A discussion of the chemistry of some minor constituents in the stratosphere and troposphere, Pure Appl. Geophys., 106-108, 1385-1399, 1973.

Danielsen, E. F.: Stratospheric-tropospheric exchange based on radioactivity, ozone and potential vorticity, J. Atmos. Sci., 25, 502$518,1968$.

Davies, T. D. and Schuepbach, E.: Episodes of high ozone concentrations at the earth's surface resulting from transport down from the upper troposphere/lower stratosphere: A review and case studies, Atmos. Environ., 28(1), 53-68, 1994.

Dibb, J. E., Meeker, L. D., Finkel, R. C., Southon, J. R., Caffee, M. W., Barrie, L. A.: Estimation of the stratospheric input to the Arctic troposphere: ${ }^{7} \mathrm{Be}$ and ${ }^{10} \mathrm{Be}$ in aerosols at Alert, Canada. J. Geophys. Res. 99, 12 855-12 864, 1994.

ECMWF, User Guide to ECMWF Products 2.1, Meteorological Bulletin M3.2, ECMWF, Reading, UK, 1995.

Eisele, H., Scheel, H. E., Sladkovic, R., and Trickl, T.: Highresolution lidar measurements of stratosphere-troposphere exchange, J. Atmos. Sci. 56, 319-330, 1999.

Elbern, H., Kowol, J., Sladkovic, R., and Ebel, A.: Deep stratospheric intrusions: A statistical assessment with model guided analyses, Atmos. Environ., 31(19), 3207-3226, 1997.

Emanuel, K. A. and Zivkovic-Rothman, M.: Development and evaluation of a convection scheme for use in climate models, J. Atmos. Sci. 56, 1766-1782, 1999.

Fabian, P. and Pruchniewicz, P. G.: Meridional distribution of ozone in the troposphere and its seasonal variations, J. Geophys. Res., 82, 2063-2073, 1977.

Follows, M. J. and Austin, J. F.: A zonal average model of the stratospheric contributions to the tropospheric ozone budget, J. Geophys. Res., 97(D16), 18 047-18 060, 1992.

Forster, C., Stohl, A., James, P., and Thouret, V.: The residence times of aircraft emissions in the stratosphere using a mean emissions inventory and emissions along actual flight tracks, J. Geophys. Res., 108(D12), doi: 10.1029/2002JD002515, 2003.

Galani, E., Balis, D., Zanis, P., Zerefos, C. S., Papayannis, A., Wernli, H., Gerasopoulos, E.: Observations of StratosphereTroposphere Exchange events over eastern Mediterranean using a ground-based lidar system, J. Geophys. Res. 108(D12), doi: 10.1029/2002JD002596, 2003. 
Gerasopoulos, E., Zanis, P., Stohl, A., Zerefos, C. S., Papastefanou, C., Ringer, W., Tobler, L., Huebener, S., Kanter, H. J., Tositti, L., and Sandrini, S.: A climatology of ${ }^{7} \mathrm{Be}$ at four high-altitude stations at the Alps and the Northern Apennines, Atmos. Environ., 35/36, 6347-6360, 2001.

Harris, J. M., Oltmans, S. J., Dlugokencky, E. J., Noveli, P. C., Johnson, B. J., and Mefford, T.: An investigation into the source of springtime tropospheric ozone maximum at Mauna Loa Observatory, Geophys. Res. Lett., 25(11), 1895-1898, 1998.

Holton, J. R., Haynes, P. H., McIntyre, E. M., Douglass, A. R., Rood, R. B., and Pfister, L.: Stratosphere-troposphere exchange, Rev. Geophys., 33, 403-439, 1995.

James, P., Scheel, H. E., Stohl, A., and Trickl, T.: Deep Stratospheric Air Intrusions Case Studies and Climatology, Procced. of EUROTRAC Symposium 2002, P. M. Midgley, M. Reuther (Eds), Margraf Verlag (Germany 2002), contribution TOR-12 (5 pp. on CD), 2002.

James, P., Stohl, A., Forster, C., Eckhardt, S., Seibert P., and Frank, A.: A 15-year climatology of stratosphere-troposphere exchange with a Lagrangian particle dispersion model, Part A: Methodology and mean climate, J. Geophys. Res., 108(D12), doi: 10.1029/2002JD002639, 2003.

Jordan, C. E., Dibb, J. E., and Finkel, R. C.: ${ }^{10} \mathrm{Be} /{ }^{7}$ Be tracer of atmospheric transport and stratosphere-troposphere exchange, J. Geophys. Res., 108(D8), doi:10.1029/2002JD002395, 2003.

Junge, C. E.: Global ozone budget and exchange between stratosphere and troposphere, Tellus, 14, 363-377, 1962.

Kentarchos, A. S., Roelofs, G. J., Lelieveld, J., and Cuevas, E.: On the origin of elevated surface ozone concentrations at Izana Observatory, Tenerife during late March 1996, Geophys. Res. Lett., 27(22), 3699-3702, 2000.

Langford, A. O., Masters, C. D., Proffitt, M. H., Hsie, E. Y., Tuck, A. F.: Ozone measurements in a tropopause fold associated with a cut-off low system, Geophys. Res. Lett., 23(18), 2501-2504, 1996.

Lelieveld, J. and Dentener, F.: What controls tropospheric ozone, J. Geophys. Res., 105(3), 3543-3563, 2000.

Logan, J. A.: Tropospheric Ozone: Seasonal Behavior, Trends, and Anthropogenic Influence, J. Geophys. Res., 90(D6), 10463 $10482,1985$.

Monks, P. S.: A review of observations and origins of the spring ozone maximum, Atmos. Environ., 34(21), 3545-3561, 2000.

Penkett, S. A. and Brice, K. A.: The spring maximum in photooxidant in the Northern hemisphere troposphere, Nature, 319, 655-657, 1986

Raisbeck, G. M., Yiou, F., Fruneaou, M., Loiseaux, J.M., Lieuvin, M., and Ravel, J. C.: Cosmogenic Be-10/Be-7 as a probe for atmospheric transport processes, Geophys. Res. Lett., 8, 10151018, 1981.

Roelofs, G. J. and Lelieveld, J.: Model study of the influence of cross-tropopause $\mathrm{O} 3$ transports on tropospheric $\mathrm{O}_{3}$ levels, Tellus, 49B, 38-55, 1997.

Roelofs, G. J., Kentarchos, A. S., Trickl, T., Stohl, A., Collins, W. J., Crowther, R., Hauglustaine, D., Klonecki, A., Law, K., Lawrence, M., von Kuhlmann, R., and van Weele, M.: Intercomparison of tropospheric chemistry models: simulated ozone transport in a tropopause folding event, J. Geophys. Res., in press, 2003.

Schuepbach, E., Davies, T. D., and Massacand, A. C.: An unusual springtime ozone episode at high elevation in the Swiss Alps; contributions both from cross-tropopause exchange and from the boundary layer, Atmos. Environ., 33, 1735-1744, 1999a.

Schuepbach, E., Davies, T. D., Massacand, A. C., and Wernli, H.: Mesoscale modelling of vertical atmospheric transport in the Alps associated with the advection of a tropopause fold a winter ozone episode, Atmos. Environ., 33, 3613-3616, 1999b.

Singh, H. B., Ludwig, F. L., and Johnson, W. B.: Tropospheric ozone: Concentrations and variabilities in clean remote atmospheres, Atmos. Environ., 12, 2185-2196, 1978.

Sprenger, M. and Wernli, H.: A northern hemispheric climatology of cross-tropopause exchange for the ERA15 time period (1979-1993), J. Geophys. Res., 108(D12), doi: 10.1029/2002JD002636, 2003.

Stohl, A., Hittenberger, M., and Wotawa, G.: Validation of the Lagrangian particle dispersion model FLEXPART against large scale tracer experiment data, Atmos. Environ., 32, 4245-4264, 1998.

Stohl, A. and Trickl, T.: A textbook example of long-range transport: Simultaneous observation of ozone maxima of stratospheric and North American origin in the free troposphere over Europe, J. Geophys. Res., 104, 30 445-30 462, 1999.

Stohl, A., Spichtinger-Rakowsky, N., Bonasoni, P., Feldmann, H., Memmesheimer, M., Scheel, H. E., Trickl, T., Hubener, S., Ringer W., and Mandl, M.: The influence of stratospheric intrusions on alpine ozone concentrations, Atmos. Environ., 34(9), 1323-1354, 2000.

Stohl, A., Bonasoni, P., Cristofanelli, P., Collins, W., Feichter, J., Frank, A., Forster, C., Gerasopoulos, E., Gäggeler, H., James, P., Kentarchos, T., Kreipl, S., Kromp-Kolb, H., Krüger, B., Land, C., Meloen, J., Papayannis, A., Priller, A., Seibert, P., Sprenger, M., Roelofs, G. J., Scheel, E., Schnabel, C., Siegmund, P., Tobler, L., Trickl, T., Wernli, H., Wirth, V., Zanis, P., Zerefos, C.: Stratosphere-troposphere exchange a review, and what we have learned from STACCATO, J. Geophys. Res., 108(D12), doi:10.1029/2002JD002490, 2003.

Wernli, H.: A Lagrangian-based analysis of extratropical cyclones. II: A detailed case study, Q. J. R. Meteorol. Soc., 123, 16771706, 1997.

Wernli, H. and Bourqui, M.: A Lagrangian "1-year climatology" of (deep) cross- tropopause exchange in the extratropical Northern Hemisphere, J. Geophys. Res., 107(D2), 4021, doi:10.1029/2001JD000812, 2002.

Wimmers, A. J., Moody, J. L., Browell, E. V., Hair, J. W., Grant, W. B., Butler, C. F., Fenn, M. A., Schmidt, C. C., Li, J., and Ridley B. A.: Signatures of tropopause folding in satellite imagery, J. Geophys. Res., 108(D4), doi: 10.1029/2001JD001358, 2003.

World Meteorological Organization (WMO), Atmospheric ozone 1985, vol. 1, Rep. 16, 1986.

Zanis, P., Schuepbach, E., Gaeggeler, H. W., Huebener, S., and Tobler, L.: Factors controlling Berrylium-7 at Jungfraujoch in Switzerland, Tellus, 51(4), 789-805, 1999.

Zanis, P., Gerasopoulos, E., Priller, A., Schnabel, C., Stohl, A., Zerefos, C. S., Gäggeler, H. W., Tobler, L., Kubik, P. W., Kanter, H. J., Scheel, H. E., Luterbacher, J., and Berger, M.: An estimate of the impact of Stratosphere-to-Troposphere Transport (STT) on the lower free tropospheric ozone over the Alps using ${ }^{10} \mathrm{Be}$ and ${ }^{7} \mathrm{Be}$ measurements, J. Geophys. Res., 108(D12), doi: 10.1029/2002JD002604, 2003. 